\title{
INFLUENCE OF ANTIOXIDANT EFFECT OF STOBADINE DERIVATIVE IN CONDITION OF KIDNEY ISCHEMIA-REPERFUSION IN A PRE-CLINICAL EXPERIMENT (EFFECT IN THERAPY)
}

\author{
Lenka Bartošíkováa, Jiří Nečasa ${ }^{a}$, Luděk Benešb, Eva Janoštíkováa, Tomáš Bartošík ${ }^{c}$, \\ Jarmila Klusáková, Tomáš Floriana, Marek Frydrycha, Jan Juřica ${ }^{\mathrm{e}}$
}

\author{
a Department of Human Pharmacology and Toxicology, Faculty of Pharmacy, University of Veterinary and Pharmaceutical \\ Sciences, Brno, Czech Republic \\ b Department of Chemical Drugs, University of Veterinary and Pharmaceutical Sciences, Brno \\ c Traumatological Hospital, Brno \\ d Pathological - anatomic Institution, Faculty Hospital U sv. Anny, Brno \\ e Department of Biochemistry, Faculty of Medicine, Masaryk University, Brno \\ e-mail: bartosikoval@vfu.cz
}

Received: June 10, 2005; Accepted: September 25, 2005

Key words: Stobadine derivative/Ischemia-reperfusion/Antioxidative enzymes/Laboratory rat

The goal of the study was to monitor the antioxidative effect of stobadine derivative under conditions of ischemiareperfusion of laboratory rat kidney tissue. 40 animals were subjected to kidney tissue ischemia (60 min) followed by reperfusion (10 $\mathrm{min})$. After that, the animals were divided by random selection into 4 groups $(\mathrm{n}=10)$. The treated groups were given stobadine derivative in peroral doses of 5,10 and $20 \mathrm{mg} / \mathrm{kg}$ in $0.5 \%$ solution of Avicel once a day, the placebo group was given only the solution of Avicel. One group ( $n=10)$ was an intact group (without ischemiareperfusion and without treatment), for comparison. Once a week, selected laboratory parameters were determined in all animals. On the $15^{\text {th }}$ day the animals were exsanquined and organs were recovered for histopathological examination. We discovered a statistically significant changes of the superoxiddismutase and glutathione peroxidase catalytic activity; changes of total antioxidative capacity and malondialdehyde in the treated groups compared to the groups of placebo and intact. Other examined laboratory parameters (creatinine, urea and uric acid in blood; creatinine, urea, total protein in urine; diuresis) exhibited significant changes too. The results of biochemical examination show a protective antioxidative effect of the compound studied. The results of histopathological examination support this assumption.

\section{INTRODUCTION}

Stobadine, (-)-cis-2,8-dimethyl-2,3,4,4a,5,9b-hexahydro$1 \mathrm{H}$-pyrido[4,3b]indole was developed in the Institute of Experimental Pharmacology of the Slovak Academy of Sciences (Bratislava) and synthetized in co-operation with the Institute of Organic Chemistry and Biochemistry of the Czechoslovak Academy of Sciences (Prague). It is a pyridoindole derivative with a cardioprotective, anti-hypoxic and anti-arrythmical effect ${ }^{1}$.

Acylderivative of stobadine - (heptanoyl) stobadine - was prepared by the reaction of stobadine base with heptanoylchloride. The applied substance was in an oxalate form. In the preliminary in vitro studies the stobadine acyl derivative proved a remarkable antioxidant activity. The objective of the study was to analyse the dependence of the antioxidative effect of the applied dose of stobadine derivative during therapeutic administration in the conditions of ischemia-reperfusion of kidney in the laboratory rat.

The study and its experimental protocol were approved and monitored by the Ethics Committee of the
University of Veterinary and Pharmaceutical Sciences in Brno. The state of health of all animals was inspected regularly several times a day both during the acclimation of the animals and in the course of the whole experiment performed by the work group whose members are holders of the Eligibility Certificate issued by the Central Commission for Animal Protection pursuant to Section 17 of the Czech National Council Act No 246/1992 Coll. on animal protection against maltreatment.

\section{MATERIAL AND METHODS}

Male Wistar SPF laboratory rats (supplied by AnLab, Praha) were used in the study. All animals were of the same age and comparable weight $(250 \pm 10 \mathrm{~g})$. They were housed in a room with a standard temperature and light regime, fed a standard M1 diet for small laboratory animals, and watered ad libitum. After 10 days of acclimation, 50 animals were randomized in 5 groups $(n=10)$. One group was intact. Four groups underwent laparotomy 
in general anaesthesia ( $2 \%$ Rometar $0.5 \mathrm{ml}+$ Narkamon $10 \mathrm{ml}$, dose $0.5 \mathrm{ml}$ solution / $100 \mathrm{~g}$ of the rat body mass). Ischemia-reperfusion injury was induced by applying a vascular clamp on the left renal artery for $60 \mathrm{~min}$ with subsequent $10 \mathrm{~min}$ renal reperfusion. After the reperfusion period each animal (including those of the intact group) was put into its own metabolic cage. For 15 days all the animals were breed in these cages. Stobadine derivative was suspended in $2 \mathrm{ml}$ of $0.5 \%$ Avicel solution. Three of four operated groups were treated with tested substance - orally by gastric sound once a day in different doses: $5 \mathrm{mg} / \mathrm{kg}, 10 \mathrm{mg} / \mathrm{kg}$ and $20 \mathrm{mg} / \mathrm{kg}$. Placebo group was given only $2 \mathrm{ml}$ of $0.5 \%$ Avicel the same way. The health condition was controlled and the urine was collected, measured and analysed every day at the same time. The $15^{\text {th }}$ day all the animals were exsanguinated in general anaesthesia (2\% Rometar $0.5 \mathrm{ml}+$ Narkamon $10 \mathrm{ml}$, dose $0.5 \mathrm{ml}$ solution / $100 \mathrm{~g}$ of the rat body mass) by blood collection from the left ventricle and the reperfused kidney was recovered. Selected laboratory markers in blood were assessed: superoxide dismutase (SOD), glutathione peroxidase (GSHpx), total antioxidative capacity (AOC) using RANDOX testing kits (Dublin, Ireland), in COBAS MIRA S automatic analyser, and malondialdehyde (MDA) was analysed spectrophotometrically using the TBARs method ${ }^{2}$, creatinine, urea and uric acid were assessed by standard laboratory methods. Creatinine, urea and total protein were analysed by standard laboratory methods in urine. The samples of the reperfused kidney tissue were fixed in neutral 10\% formaldehyde, stained with hematoxylin-eosin and examined by experienced histopathologist using an optical microscope. The results were processed by the Microsoft Excel ${ }^{\circledR}$ table processor and statistically interpreted using a non-pair T-test. The value $\mathrm{p} \leq 0.05$ was considered significant.

\section{RESULTS}

Results of laboratory analysis in blood (Table 1 and 2) can be summarized as follows: In comparison with animals of intact group, rats that had been subjected to renal ischemia-reperfusion (placebo group) showed a significant increase of MDA level and significant decrease of SOD and GSHPX activity. AOC values of placebo group showed no significant difference in comparison with intact group in our experiment, as shown in Table 1. A statistically significant increase of SOD values $(\mathrm{p} \leq 0.01)$ was detected in the tretaed groups, compared with the placebo and the intact group. A significant decrease in GSHPx values ( $\mathrm{p} \leq 0.01$ ) was detected in all groups treated with stobadine derivative compared with the intact group.

Treatment with stobadine derivative at the doses of 5,10 , and $20 \mathrm{mg} / \mathrm{kg}$ produced a significant increase of AOC values $(p \leq 0.01)$ of treated groups compared with the placebo and intact group. Also, the treatment with stobadine derivative at the doses of 5,10 , and 20 $\mathrm{mg} / \mathrm{kg}$ produced a significant decrease of MDA values
( $p \leq 0.01$ ) of treated groups compared with the placebo group. A significant increase of creatinine values $(\mathrm{p} \leq$ 0.01) was detected in the treated groups, compared with the placebo and the intact group. Comparison of the values obtained from the placebo group and the intact group showed an increase $(\mathrm{p} \leq 0.01)$ of the creatinine value in the placebo group. Significant changes of urea values $(p \leq$ 0.01 ) were detected in the treated groups, compared with the intact group. Comparison of the values obtained from the placebo group and intact group showed an increase $(\mathrm{p} \leq 0.01)$ of the urea value in the placebo group. A significant increase of uric acid value $(\mathrm{p} \leq 0.01)$ was detected in the treated groups, compared with the placebo and the intact group.

Results of laboratory analysis in urine (Table 3 ) can be summarized as follows: The significant changes of creatinine values ( $\mathrm{p} \leq 0.05 ; \mathrm{p} \leq 0.01)$ were detected in all groups treated with stobadine derivative, compared with the placebo and intact group. Comparison of the values obtained from the placebo group and the intact group showed an increase $(\mathrm{p} \leq 0.01)$ of the creatinine value in the placebo group.

A significant increase of urea value $(\mathrm{p} \leq 0.01)$ was detected in the treated groups, compared with the placebo and intact groups. Comparison of the values obtained from the placebo group and the intact group showed an increase $(p \leq 0.01)$ of the urea value in the placebo group. Significant changes of total protein values $(\mathrm{p} \leq 0.05$; $\mathrm{p} \leq 0.01$ ) were detected in the treated groups, compared with the placebo and intact group. Comparison of the values obtained from the placebo group and the intact group showed an increase $(\mathrm{p} \leq 0.01)$ of the creatinine value in the placebo group. Significant changes of daily diuresis ( $p \leq 0.01$ ) were detected in all treated groups, compared with the intact group. Comparison of the values obtained from the placebo group and intact group showed a decrease $(p \leq 0.01)$ of daily diuresis in the placebo group.

Results of histopathological examination were as follows: In the placebo group massive hemorrhage in the interstitium was observed in all samples, especially on the cortex and medulla boundaries. Hemorrhage occured in the glomerule area (Bowman's capsule and capillary convolusion) as well as in the medulla. The channels have regressively changed epithelia from the simple edema to epithelia necrosis with all the above described features. In the lumina there is mostly a proteinic content with hyaline cylinder formation. The accompanying edema and the generally increased cellularity of the glomerule are inflammatory reactive. The more marked inflammatory infiltrate is smaller than in the treated groups in the form of sporadic lymphocytes with rare polynuclears. The total average score was oscillating from 5 to 7 . In the intact control group, haemorrhage occurred only accidentally, most probably caused by contusion. In the treated groups, the best protective effect was detected at the dose $10 \mathrm{mg} / \mathrm{kg}$ ( score 5,0). 
Table 1. Values of studied laboratory parameters expressed as $x \pm \mathrm{SD}$

\begin{tabular}{|l|c|c|c|c|}
\hline \multicolumn{1}{|c|}{$\begin{array}{c}\text { Group of animals } \\
(\mathrm{n}=10)\end{array}$} & $\begin{array}{c}\text { SOD } \\
(\mathrm{U} / \mathrm{ml})\end{array}$ & $\begin{array}{c}\text { GSHPx } \\
(\mu \mathrm{kat} / \mathrm{l})\end{array}$ & $\begin{array}{c}\text { AOC } \\
(\mathrm{mmol} / \mathrm{l})\end{array}$ & $\begin{array}{c}\text { MDA } \\
(\mathrm{mmol} / \mathrm{l})\end{array}$ \\
\hline $\begin{array}{l}\text { Treated }(5 \mathrm{mg} / \mathrm{kg} \\
\text { of heptanoylstobadine })\end{array}$ & $162.11 \pm 7.30 * *$ & $1208.25 \pm 19.22++$ & $0.54 \pm 0.01 * *++$ & $2.77 \pm 0.59 * *++$ \\
\hline $\begin{array}{l}\text { Treated }(10 \mathrm{mg} / \mathrm{kg} \\
\text { of heptanoylstobadine })\end{array}$ & $191.98 \pm 9.01 * *++$ & $1255.88 \pm 59.87++$ & $0.60 \pm 0.03 * *++$ & $2.21 \pm 0.04 * *++$ \\
\hline $\begin{array}{l}\text { Treated }(20 \mathrm{mg} / \mathrm{kg} \\
\text { of heptanoylstobadine })\end{array}$ & $223.01 \pm 12.46 * *++$ & $1285.75 \pm 17.04++$ & $0.55 \pm 0.007 * *++$ & $1.88 \pm 0.32 * *$ \\
\hline Placebo group & $69.51 \pm 2.89 \bullet$ & $1329.00 \pm 91.41 \bullet$ & $0.41 \pm 0.03$ & $17.17 \pm 1.12 \bullet$ \\
\hline Intact group & $167.04 \pm 3.24$ & $1509.38 \pm 147.93$ & $0.44 \pm 0.03$ & $1.89 \pm 0.16$ \\
\hline
\end{tabular}

${ }^{*} \mathrm{p} \leq 0.05$ treated vs placebo group, ${ }^{* *} \mathrm{p} \leq 0.01$ tretaed vs placebo group, $+\mathrm{p} \leq 0.05$ treated vs intact group, $++\mathrm{p} \leq 0.01$ treated vs intact group, $\bullet \mathrm{p} \leq 0.05$ placebo vs intact group, $\bullet \bullet \mathrm{p} \leq 0.01$ placebo vs intact group

Table 2. Values of studied laboratory parameters expressed as $\times \pm \mathrm{SD}$

\begin{tabular}{|c|c|c|c|}
\hline $\begin{array}{l}\text { Group of animals } \\
\qquad(\mathrm{n}=10)\end{array}$ & $\begin{array}{l}\text { Creatinine } \\
(\mu \mathrm{mol} / 1)\end{array}$ & $\begin{array}{c}\text { Urea } \\
(\mathrm{mmol} / 1)\end{array}$ & $\begin{array}{l}\text { Uric acid } \\
(\mu \mathrm{mol} / 1)\end{array}$ \\
\hline $\begin{array}{l}\text { Treated }(5 \mathrm{mg} / \mathrm{kg} \\
\text { of heptanoylstobadine })\end{array}$ & $51.16 \pm 2.25 * *++$ & $7.65 \pm 0.94++$ & $25.71 \pm 3.15 * *++$ \\
\hline $\begin{array}{l}\text { Treated }(10 \mathrm{mg} / \mathrm{kg} \\
\text { of heptanoylstobadine })\end{array}$ & $51.25 \pm 2.89 * *++$ & $7.98 \pm 1.03++$ & $36.23 \pm 4.69 * *++$ \\
\hline $\begin{array}{l}\text { Treated }(20 \mathrm{mg} / \mathrm{kg} \\
\text { of heptanoylstobadine })\end{array}$ & $43.53 \pm 1.83++$ & $7.12 \pm 0.47++$ & $33.60 \pm 10.58 * *++$ \\
\hline Placebo group & $44.83 \pm 1.78 \bullet \bullet$ & $7.46 \pm 0.43 \bullet \bullet$ & $19.54 \pm 4.08$ \\
\hline Intact group & $40.68 \pm 1.77$ & $6.35 \pm 0.25$ & $17.21 \pm 1.86$ \\
\hline
\end{tabular}

For meanings of marks used for the statistic significance, see explanations for Tab. 1

Table 3. Values of studied laboratory parameters expressed as $\times \pm \mathrm{SD}$

\begin{tabular}{|l|c|c|c|c|}
\hline \multicolumn{1}{|c|}{$\begin{array}{c}\text { Group of animals } \\
(\mathrm{n}=10)\end{array}$} & $\begin{array}{c}\text { Creatinine } \\
(\mu \mathrm{mol} / \mathrm{l})\end{array}$ & $\begin{array}{c}\text { Urea } \\
(\mathrm{mmol} / \mathrm{l})\end{array}$ & $\begin{array}{c}\text { Total protein } \\
(\mathrm{g} / \mathrm{l})\end{array}$ & $\begin{array}{c}\text { Diuresis/24 hours } \\
(\mathrm{ml})\end{array}$ \\
\hline $\begin{array}{l}\text { Treated }(5 \mathrm{mg} / \mathrm{kg} \\
\text { of heptanoylstobadine })\end{array}$ & $\begin{array}{c}2735.93 \pm 496.85 \\
++\end{array}$ & $\begin{array}{c}711.26 \pm 89.29 \\
* *++\end{array}$ & $\begin{array}{c}1.99 \pm 0.33 \\
*++\end{array}$ & $\begin{array}{c}18.13 \pm 1.81 \\
++\end{array}$ \\
\hline $\begin{array}{l}\text { Treated }(10 \mathrm{mg} / \mathrm{kg} \text { of } \\
\text { heptanoylstobadine })\end{array}$ & $\begin{array}{c}2726.80 \pm 270.00 \\
*++\end{array}$ & $\begin{array}{c}647.68 \pm 95.31 \\
* *++\end{array}$ & $\begin{array}{c}1.75 \pm 0.63 \\
++\end{array}$ & $\begin{array}{c}22.06 \pm 5.14 \\
++\end{array}$ \\
\hline $\begin{array}{l}\text { Treated }(20 \mathrm{mg} / \mathrm{kg} \text { of } \\
\text { heptanoylstobadine })\end{array}$ & $\begin{array}{c}3294.61 \pm 243.96 \\
++\end{array}$ & $\begin{array}{c}739.68 \pm 98.95 \\
* *++\end{array}$ & $\begin{array}{c}1.75 \pm 0.26 \\
++\end{array}$ & $\begin{array}{c}16.63 \pm 1.41 \\
*++\end{array}$ \\
\hline $\begin{array}{l}\text { Placebo group } \\
\text { Intact group }\end{array}$ & $\begin{array}{c}3262.61 \pm 461.24 \\
\bullet\end{array}$ & $\begin{array}{c}404.93 \pm 61.73 \\
\bullet\end{array}$ & $\begin{array}{c}1.38 \pm 0.61 \\
\bullet\end{array}$ & $\begin{array}{c}19.63 \pm 3.41 \\
\bullet\end{array}$ \\
\hline
\end{tabular}

For meanings of marks used for the statistic significance, see explanations for Tab. 1. 


\section{DISCUSSION}

Free radicals play an important role in the pathogenesis of kidney ischemia-reperfusion injury ${ }^{3}$. In our study, the antioxidative action of stobadine derivative in the conditions of kidney ischaemia-reperfusion in the laboratory rat was analysed.

Statistically significant higher SOD concentrations found in the medicated groups confirm the readiness of the organism to the destruction of superoxide. In our study, the activity of SOD in treated groups was approximately three times higher than in the intact group. The highest effect on SOD concentration increase was declared at the dose $20 \mathrm{mg} / \mathrm{kg}$.

Statistically significant was the decrease of GSHPx concentrations in all medicated groups. At the dose $20 \mathrm{mg} / \mathrm{kg}$ the GSHPx concetration was the highest. Because the analysed enzymes are intracellular and their activities follow one another, we can suppose that their concentrations are influenced by the type of ROS that is just present. It is possible, that the massive production of SOD was the physiological answer, supported by the effect of stobadine derivative, to the presence of huge amount of superoxide, whereas GSHPx didn't have hydrogenperoxide enought at the moment of the assessment - and thus its concentrations were not increased yet. The views on change of SOD and GSHPx concentrations caused by the declining kidney function vary - some authors declare increased concentrations ${ }^{4}$, others decreased ${ }^{3,5}$ or unaffected concentrations $s^{6}$.

AOC is not the most specific determinate of antioxidative abilities of the organism, because it is a sum of effects of many antioxidative factors ${ }^{7}$. Uric acid which is the final product of degradation of AMP is a very important antioxidant in blood. In our study uric acid was significantlly $(p \leq 0.01)$ increased after the administration of stobadine derivative at all the doses. The uric acid should be considered to be not only a nitrogenous metabolite of purine compounds but it also has significant antioxidative effects. The authors differ in their views on the AOC changes due to possibly declining function of kidneys ${ }^{8,9}$.

MDA is a toxic by-product of lipoperoxidation and its concentration usually correlate with intensity of action of ROS in lipid membranes and thus also with the severity of oxidative injury. Increased concentration of MDA could be caused by decreased renal elimination during renal failure ${ }^{10}$. Although the TBARs method ${ }^{2}$ with spectrophotometrical assessment is not the most specific one, it is sufficient for our measurements, because important is the difference between the assessed concentrations in medicated groups and placebo or intact group, not the exact quantity of TBARs products.

Acute renal failure was evident by the placebo group above all. Elevated levels of creatinine and urea in blood and urine, and reduction of daily diuresis are the results of homeostatic disbalance caused by renal failure. After fif- teen days of stobadine derivative medication biochemical markers in blood almost reached the physiological levels. In the similar type of study ${ }^{3}$ the reperfusion period lasted only 24 hours and thus the differences between groups treated with flavonoid naringin and the sham groups were much more significant. On the other hand, biochemical markers in urine showed still significant differences ( $\mathrm{p} \leq$ 0.05 or $p \leq 0.01$ ) between treated and placebo or intact groups.

Histopathological examination revealed severe lesions in the kidney of untreated placebo group of rats (ischemiareperfusion) compared with intact group. Much of this tubular and glomerular dysfunction has been postulated to occur during the reperfusion period following anoxia, and generation of ROS has been postulated as one of the major factors contributing to the reperfusion injury. The role of reactive oxygen species in human kidney transplantation seems to correlate with results obtained in animal studies ${ }^{3}$.

In our study, the potential protective effect of stobadine derivative is demonstrated in the therapy of ischemicreperfusion injury to kidney in the laboratory rat. This assumption is supported by the results of the evaluation of histopathological findings in the examined kidney samples.

\section{ACKNOWLEDGEMENT}

The study was supported by grant No NL/7455-3 of the Internal Grant Agency, Ministry of Health, Czech Republic.

\section{REFERENCES}

1. Knezl V, Sotníková R, Okruhlicová L, Navarová J. (1999) Effect of stobadine on cardiac injury induced by ischemia and reperfusion. Life Sci 65, 1933-4.

2. Kosugi H, Kikugawa K. (1989) Potential thiobarbituric acid-reactive substances in peroxidized lipids. Free Radic Biol Med 17, 205-7.

3. Singh D, Chopra K. (2004) The effect of naringin, a bioflavonoid on ischemia-reperfusion induced renal injury in rats. Pharmacol Res 50, 187-93.

4. Chen ZY, Chan PT, Ho KY, Fung KP, Wang J. (1996) Antioxidant activity of natural flavonoids is governed by number and location of their aromatic hydroxyl groups. Chem Phys Lipids 79, 157-63.

5. Racek, J, Veselá E, Holeček V, Treška V. (1995) The significance of free radicals in patients with renal failure and during kidney transplantation. Klin Biochem Metab 24 Suppl, 4-6.

6. Duračková Z. (1997) Antioxidanty v dobrom aj zlom. Clin Biochem Met 5, 194-9.

7. Racek J. Oxidační stres a možnosti jeho ovlivnění (Oxidative stress and possibilities of its reduction). Prague: Galén, 2003

8. Jackson P, Loughrey CM, Lightbody JH, McNamee PT, Young IS. (1995) Effect of hemodialysis on total antioxidant capacity and serum antioxidants in patients with chronic renal failure. Clin Chem $41,1135-8$.

9. Toborek M, Wasik T, Drozdz M, Klin M, Magnerwrobel K, Kopiecznagrzebieniak E. (1992) Effect of hemodialysis on lipid peroxidation and antioxidant system in patients with chronic renal failure. Metabolism 41, 1232-99.

10. Racek J, Eiselt J, Holeček V, Veselá E, Krejčová I, Třeška V, Opatrný K, Valenta J. (1997) Free radicals and kidney disease. Klin Biochem Metab 26, 92-7. 